\title{
JERZY STEFAŃSKI \\ Miejsce i rola kantyków w księdze Liturgii Godzin. Kwestie redakcyjne
}

W dotychczasowym, przedsoborowym Breviarium Romanum [odtąd $=B R$ ], kantyki, czyli śpiewy, hymny zaczerpnięte ze Starego Testamentu, występowały wyłącznie w jutrzni (laudes). Psalmodia tejże godziny kanonicznej obejmowała cztery psalmy plus kantyk. Kantyk znajdował się zawsze na czwartym miejscu, czyli po trzech kolejnych psalmach następował kantyk, a potem na piątym miejscu ostatni z czterech psalmów. Psalmodia zaś, jak wiadomo, w BR była w układzie jednego tygodnia, natomiast laudes na każdy dzień były podwójne (I laudes oraz II laudes).

Problematyka rewizji kantyków należała do kompetencji Grupy Studyjnej (Consilium) nr III De psalmis distribuendis, której przewodniczył I. Pascher ${ }^{1}$.

Jeden z pierwszych dokumentów powyższej Grupy podpisany przez jej sekretarza V. Raffa ${ }^{2}$, przypomina odnośnie do kwestii kantyków ich występowanie

Jerzy S T E F A Ń S K I, ks. prof. dr hab., emerytowany profesor Wydziału Teologicznego Uniwersytetu im. Adama Mickiewicza w Poznaniu, e-mail: giorgio_st@ poczta.onet.pl

${ }^{1}$ Dla zapoznania się z panoramą prac tejże Grupy odnośnie do nowej redakcji i układu psalmów w księdze Liturgii Godzin - zob. J. S te fań s ki: Dystrybucja psalmów w posoborowej reformie księgi Liturgii Godzin. Kwestie redakcyjne. W: „Roczniki Liturgiczne”. T. 56: $2009 \mathrm{nr}$ 1 s. $449-479$.

NB. Aby nie powtarzać wcześniej już przekazanych informacji na temat organizacji prac nad redakcją nowej księgi Brewiarza, przeprowadzonych przez różne Grupy Studyjne wchodzące w skład Consilium ad exsequendam Constitutionem de Sacra liturgia (1964), odsyłamy do - J. S t e fan s k i: Prace redakcyjne nad posoborowa księga Liturgii Godzin. Konspekt historyczny. W: Mirabile laudis canticum. Liturgia Godzin: Dzieje i teologia. Red. H. S o b e c z ko. Opole 2008 s. 115-136.

${ }^{2}$ Chodzi tutaj o dokument niezbyt precyzyjnie opisany. Zapewne, ze względu na jego treść napisany między 16 IV 1964 (Schemata n. 5), a 10 V 1964 (Schemata n. 9). Opatrzony jest 
w jutrzni (kantyki ze Starego Testamentu), ale proponuje po raz pierwszy możliwość ich zastosowania w nieszporach, zamiast piątego psalmu. Propozycja ta nie podaje, na tym etapie prac redakcyjnych, żadnych dalszych precyzji tekstowych. Takowe, opowiadające się za kantykami z Nowego Testamentu w nieszporach pojawiły się już w maju $1964^{3}$. Relatywny dokument przypomina najpierw, że trzy kantyki zaczerpnięte z Nowego Testamentu stanowią trwały element modlitewny jutrzni, nieszporów oraz komplety (Benedictus, Magnificat, Nunc dimittis), będąc zarazem ukoronowaniem tychże godzin kanonicznych. Równocześnie w listach św. Pawła, wg zgodnej opinii wielu egzegetów, rozpoznamy teksty o charakterze hymnologicznym, podobnie zresztą także w księdze Apokalipsy. Mogłyby one występować w miejscu piątego dotychczasowego psalmu nieszporów. Te same propozycje powtórzył I. Pascher na spotkaniu w dniach 20-21 czerwca 1964 w Rzymie zorganizowanym przez A. G. Martimorta, odpowiedzialnego za całość prac nad rewizją dotychczasowego $B R$, z udziałem wszystkich relatorów Grup Studyjnych pracujących nad nową redakcją poszczególnych elementów składowych powyższej księgi ${ }^{4}$.

W połowie lipca 1964 A. G. Martimort przesłał wszystkim pracującym nad rewizją księgi $B R$ zarys relacji, sprawozdania, które zamierzał przedstawić $\mathrm{Oj}_{5}$ com IV Sesji Plenarnej Consilium, zapowiedzianej na 28 IX-1 X 1964 rokus. W tejże relacji, odnośnie do kantyków odnajdujemy przyjęte już wcześniej przez Grupę Studyjną III ustalenia, aby w jutrzni zachować dotychczas obowiązujący podwójny zestaw kantyków ze Starego Testamentu występujący w laudes I oraz luades II. Dla nieszporów natomiast należy w przyszłości dobrać odpowiednie teksty z Nowego Testamentu (głównie z Listów św. Pawła oraz Apokalipsy), o ile zdaniem egzegetów będą one miały charakter kantyku. Mógłby on występować w psalmodii nieszporów na piątym miejscu. A. G. Martimort w następnej relacji przypomniał, że już w tzw. Kodeksie Aleksandryjskim z IV wieku, po psalmodii znajdziemy aż 12 kantyków, z tego 9 ze Starego Testamentu ${ }^{6}$. W doskonały sposób wyrażają one tajemnice paschalne. Również nie do odrzucenia są kantyki wprowadzone reformą Piusa X. Odnośnie jednak do wprowadzenia w nieszporach kantyków z Nowego Testamentu, nie ma jak dotąd jednoznacznej

symbolem 5 A, zob. Animadversiones circa distributionem psalmorum in futuro Breviario, cura D. Vincentu Raffa F. D. P. s. 1-4.

${ }^{3}$ Zob. Schemata n. 9, z dnia $10 \mathrm{~V}$ 1964, De Psalterio 2, Normae in recognitione psalterii liturgici servatae s. 1-5. tutaj s. 4-5. Warto przypomnieć, że wówczas, po raz pierwszy pojawiła się propozycja czterotygodniowej dystrybucji psałterza.

${ }_{4}^{4}$ Zob. Schemata n. 23, z dnia 19 lipca 1964, De Breviario 5, Relatio de distributione psalmorum, s. 1-10, tutaj, s. 4-5.

${ }^{5}$ Zob. Schemata n. 24, z dnia 20 lipca 1964, De Breviario 6. Dokument ten opatrzony jest „personalnym” tytułem Eruditissimi Sodales, s. 1-12, tutaj, s. $2,4$.

${ }^{6}$ Opis kodeksu oraz precyzyjny zestaw kantyków w nim zawarty podaje A. G. M a r $\mathrm{t}$ i m o r t w La Chiesa in preghiera. Introduzione alla liturgia, Brescia 1984, vol. IV, s. 239 n. 
opinii zarówno w łonie Grupy Studyjnej III, jak też wśród członków Grypy Studyjnej IX, kierującej całością prac związanych z nową redakcją $B R$. Relacja przypomniała równocześnie, że w czasie dyskusji w auli Soboru Watykańskiego II niektórzy z Ojców postulowali obecność kantyków z Nowego Testamentu w nieszporach. Nie ułatwiają rozwiązania powyższego problemu niejednolite opinie egzegetów na temat struktury kantyków niektórych zaproponowanych tekstów z Listów Pawłowych czy Apokalipsy. Powszechna zgoda wśród konsultorów dotyczy jednakże wykluczenia obecności nowych kantyków w jutrzni. Na tym etapie prac przeważała opinia, aby po psalmodii (składającej się tylko z 4 psalmów) następowały: krótkie czytanie (capitulum) ze Starego lub Nowego Testamentu, kantyk z Nowego Testamentu, kantyk ewangelijny Magnificat oraz odpowiednie zakończenie ${ }^{7}$.

Jedną z pierwszych propozycji tekstowych przyszłych kantyków zaczerpniętych z Nowego Testamentu i przeznaczonych (ewentualnie) do nieszporów przedłożył konsultor Grupy Studyjnej III - G. Pinell. Oto jego propozycje: Ap 19,1.5-7; Ap 11,17-18; Ef 1,3-10; Kol 1,12-20; 1 P 2,21-24; Ap 4,11 oraz 5,9-10; Flp 2,6-11.

W dnach 28 IX-1 X 1964 odbyła się w Watykanie IV Sesja Plenarna Consilium. Odnośnie do omawianej tutaj kwestii kantyków, członkom tego gremium zadano krótkie pytanie: czy zgadzają się na odłożenie w czasie problematyki kantyków z Nowego Testamentu, pozostawiając tę sprawę studiom przez właściwych fachowców. Na 28 obecnych Ojców Consilium, 21 głosowało placet, a 7 non placet ${ }^{9}$.

Przez następne pół roku sprawa kantyków w pracach Grupy Studyjnej III nie doznała istotnego przyspieszenia. W jutrzni nadal na 4 miejscu psalmodii zamierzano pozostawić tradycyjne kantyki ze Starego Testamentu, natomiast w nieszporach piąty psalm proponowano zastąpić kantykiem z Nowego Testamentu. Nie wskazywano jednak wówczas żadnego oficjalnego zestawu tekstów

${ }^{7}$ Zob. Schemata n. 31, z dnia 14 września 1964, De Breviario 10, Relatio generalis de reformatione Breviarii, s. 1-17, tutaj s. 6: Si supprimeretur quintus psalmus, additio cantici post capitulum fieri posset sine difficultate; ordo ex traditione servandus inter lectiones intactus remaneret, scilicet post psalmos Veteris Testamenti, capitulum sive ex Vetere sive ex Novo Testamento depromptum, canticum ex epistolis vel ex Apocalypsi, denique canticum ex Evangelio Magnificat.

${ }^{8}$ Informuje o tym maszynopisowy dokument (bez podpisu) z dnia 26 września 1964 Relatio de distributione psalmorum habita die 26. 9. 1964 in conventu Coetus IX, s. 1-2, tutaj s. 1.

${ }^{9}$ Zob. Schemata n. 50, z dnia 1 grudnia 1964, De Breviario 14, Relatio de Sessionibus quas Coetus a Studiis IX diebus 26, 27 septembris ac 1 octobris 1964 Romae habuit, s. 1-16, tutaj s. 15. 
biblijnych mogących mieć charakter kantyku (... De hac quaestione studia ulteriora indagantur $)^{10}$.

Grupa Studyjna IX ponaglała jednakże, aby odpowiedzialni za kantyki podjęli decyzje zarówno odnośnie do długości tychże dotychczasowych, tradycyjnych tekstów w jutrzni, jak też opowiedzenia się czy i jakie kantyki należy wprowadzić do nieszporów ${ }^{11}$. W odpowiedzi Grupa Studyjna III zasugerowała, aby w jutrzni skrócić kantyki z ksiąg Powtórzonego Prawa, Wyjścia oraz Habakuka, które są obecne w $B R$ w czwartek, piątek i sobotę. Dla nieszporów przewidziano dwie serie tekstów, które zostały uprzednio skonsultowane z członkami Grupy Studyjnej IV De lectionibus biblicis. Pierwszą serię już wcześniej zgłosił J. Pinell ${ }^{12}$. Drugą serię, autorstwa sekretarza Grupy Studyjnej III A. Rose, po konsultacji z egzegetą i patrologiem L. Cerfaux, tworzyły następujące teksty: 1 Kor 13,1-7; Ef 1,3-10; Kol 1,12-20; Flp 2,6-11; 1 Tm 3,16; Ap 11,17-18; Ap 12,10-12; Ap 15,3-4 ${ }^{13}$.

Grupa Studyjna IV (De lectionibus biblicis), poproszona o wyrażenie swej opinii na temat doboru tekstów z Nowego Testamentu w charakterze kantyków nieszpornych, zaleciła następujący tygodniowy ich układ:

niedziela: Kol 1,12-20;

poniedziałek: 1 Kor 13,1-7;

wtorek: Ap 4,11 + 15,3-4 (kantyk o Stworzycielu);

środa: Ap 19,1b.2a.5b.6b-8a + 21,3b-4[5a.6bc.7] (O zaślubinach baranka)

czwartek: Ap 11,17-18 + 12,10b-12a + 15,3b-4 (O sądzie Bożym);

piątek: 1 P 2,21-24;

sobota: Flp 2,6-11 lub Ef 1,3-10 14 .

Na dni 25 i 26 września 1965 roku, A. G. Martimort zwołał na cykl trzech posiedzeń wszystkich relatorów zespołów pracujących nad rewizją księgi $B R .25$ września, zgodnie z planem dyskutowano z udziałem całej Grupy Studyjnej III nad kryteriami przyszłej, nowej dystrybucji psalmów, zwłaszcza w jutrzni i nie-

${ }^{10}$ Zob. Schemata n. 73, z dnia 26 kwietnia 1965, De Breviario 20, Coetus a Studiis III: De psalmis distribuendis. Quaestiones Consilio proponendae de distributione psalmorum (ad Const. art. 91), s. 1-8, tutaj s. 2.

${ }^{11}$... Urgentior quaestio videtur de canticis ita ut Laudes cantica traditionalia servent, sed ratione habita de longitudine. De Vesperis autem decisio haberi debet utrum adhibenda sint et qualia, zob. Schemata $n$. 95, z dnia 22 maja 1965, De Breviario 26, De structura generali Breviarii. Relatio de Sessione quam Coetus a Studiis IX die 30 aprilis 1965 Romae habuit, s. 1-8, tutaj s. 5.

${ }^{12}$ Zob. przyp. 8.

${ }^{13}$ Powyższe zestawy zawarte są w Schemata $n$. 97, z dnia 31 maja 1965, De Breviario 27, De psalmis distribuendis, s. 1-4, tutaj s. 1.

${ }^{14}$ Prezentowany zestaw kantyków autorstwa Grupy Studyjnej IV zawarty jest w liście skierowanym przez relatora J. P a s c h e r a do członków Grupy Studyjnej III, opatrzonym datą 22 lipca 1965, noszącym tytuł Sodales Carissimi, s. 1-5, tutaj s. 3. 
szporach. Nieco dłużej zatrzymano się nad kwestią kantyków, przeznaczonych zarówno dla jutrzni, jak też nieszporów ${ }^{15}$. Przypomniano najpierw, że w jutrzni występują dotąd dwie serie kantyków: jedna sięga czasów starożytnych, drugą wprowadzono reformą Piusa X. Ówczesny pracownik Kongregacji Rytów L. Trimeloni chciałby przeznaczyć jedną serię na okres letni, drugą na zimowy. E. Lengeling proponował, aby w przypadku wydania przyszłej księgi $B R$ w dwóch tomach, każdemu $\mathrm{z}$ nich przydzielić osobną serię kantyków. Konsultor V. Raffa sugerował, aby drugą serię kantyków zostawić ad libitum. Relator J. Pascher opowiadał się za alternatywną praktyką recytowania kantyków stosując podział albo według zmiennych pór roku, albo według ewentualnego (przyszłego, jeszcze nie ustalonego) podziału psalmodii na tygodnie.

Dyskusję nad poszczególnymi tekstami kantyków z Nowego Testamentu rozpoczęto od wstępnego głosowania na możliwością ich włączenia do struktury nieszporów. Na 14 obecnych tylko 1 głos był non placet. Z obszernej dyskusji na temat obecności kantyków w nieszporach przytaczamy najbardziej charakterystyczne opinie konsultorów i zaproszonych ekspertów:

B. Neunheuser przypomniał, że włączenie kantyków do nieszporów jest niezgodne $\mathrm{z}$ dotychczasową tradycją. Nie będą też prezentowały szczytu tej godziny kanonicznej, gdyż taką rolę przypisuje się ewangelijnemu Magnificat. Poza tym kantyki z listów Pawłowych będą trudne pro cantu;

P. M. Gy uważał, że zaproponowane kantyki nie harmonizują treściowo z Magnificat, a taki przecież logiczny związek dostrzegamy we Mszy św. pomiędzy lekcją a Ewangelią. Zatem potrzebny byłby nowy zestaw kantyków;

J. Pascher widział w kantykach źródło radości dla modlących się kapłanów. Ewentualne trudności w relacji tekstów Starego do Nowego Testamentu nie powinna stanowić żadnego problemu, gdyż przecież same psalmy recytowane są w świetle Nowego Przymierza. Ponadto prosił on przedstawicieli zakonu benedyktyńskiego, aby zatroszczyli się w przyszłości o muzyczną formę kantyków;

H. Schmitt podkreślał, że kantyki z Nowego Testamentu wprowadzają do nieszporów wymiar bardziej uroczystej celebracji;

B. Botte z przekąsem stwierdził, że kantyki powinny być przedmiotem zainteresowania homilii, ale nie nieszporów;

15 Poniżej streszczamy zasadnicze tezy i opinie dyskutowane na tymże spotkaniu, zob. Schemata n. 136, z dnia 22 grudnia 1965, De Breviario 33, Coetus a Studiis IX: De generali structura Officii Divini. Relatio de Sessionibus quas Coetus IX Romae ad Aedes S. Martae diebus 25-26 septembris habuit, s. 1-11, tutaj s. 6-8. 
H. M. Roguet popierał inicjatywę występowania kantyków w nieszporach, gdyż w ten sposób doskonale („,mirabiliter”) ukazuje się relacje między Starym a Nowym Testamentem;

J. Wagner optował za niewielkimi zmianami dotychczasowej struktury nieszporów, wzorowanej na tradycji benedyktyńskiej, a składającej się z czterech psalmów, lektury biblijnej oraz responsorium.

Na tymże posiedzeniu omówiono i przegłosowano 8 zaproponowanych tekstów kantyków z Nowego Testamentu. Kantyk o miłości (1 Kor 13,1-7) nie zyskał przychylności większości głosujących. Tekst Ef 1,3-10 (gratiarum actio) na 14 głosujących tylko 1 głos był non placet. Podobny wynik głosowania dotyczył tekstu Kol 1,12-20 (gratiarum actio). Za kantykiem o Słudze Bożym Flp 2,6-11 opowiedziało się 10 obecnych (4 - non placet). Natomiast cztery zgłoszone teksty z Apokalipsy spotkały się z pełną aprobatą dyskutantów.

Rok później Grupa Studyjna III zaproponowała następujące kantyki z Nowego Testamentu przeznaczone do nieszporów (miały one zastępować dotychczasowy piąty psalm) ${ }^{16}$ :

1. I Cor 13,1-7: Hymnus de caritate,

2. Eph 1,3-10: Gratiarum actio,

3. Col 1,12-20: Gratiarum actio,

4. Phil 2,6-11: Hymnus de Christo "servo Dei",

5. Apc 4,11 et 5,9-10. 12,

6. Apc 11, 17-18.12,10b-12a,

7. Apc 15,3-4,

8. Apc 19,1b.2a.4b.5b.6b.7.8a.

W komentarzu do powyższego zestawu tekstów przypomniano, że jakkolwiek jest to zupełna nowość w tradycji rytu rzymskiego, to jednak kantyki z Nowego Testamentu występują w liturgii mozarabskiej. Potwierdza to studium A. W. S. Portera ${ }^{17}$, który wymienia następujące teksty: Mt 22,23-32; 1 Tm 6,12 oraz 4,12-16; Ap 15,1-4; Ap 19,5-8. Równocześnie zauważalne aktualnie odrodzenie studiów biblijnych podkreśla istnienie wielu tekstów Nowego Testamentu, które odznaczają się walorem hymnicznym. Struktura literacka takowych tekstów (śpiewów) w wielu przypadkach jest analogiczna do psalmów pochwalnych, które zaczynają się od ,zachęty”, aby następnie ukazać motywację takiego wezwania. Przykładem jest psalm 16: laudate Dominum ... quoniam confirmata est. Podobną strukturę posiadają także wszystkie prefacje mszalne. Nie należy przy tym zapominać, że omawiane tutaj kantyki są doskonałym źródłem ducho-

${ }^{16}$ Zob. Schemata n. 185, z dnia 19 września 1966, De Breviario 40 - Adnexa, De canticis Novi Testamenti, s. 1-7, tutaj s. 1-2 (łącznie z komentarzem, który poniżej streszczamy).

${ }^{17}$ Zob. A. W. S. P o r t e r: Cantica Mozarabici Officii. „EL” 49 (1935) 126-145. 
wości liturgicznej. Jest to szczególnie ważne przy zauważalnej trudności właściwej interpretacji zarówno przez świeckich, jak też osoby duchowne znaczenia psalmów, które przecież tchną duchem Starego Testamentu. Pomocą mogą tu być pisma Ojców Kościoła, którzy w psalmach widzieli figurę samego Chrystusa lub Kościoła. Należy zatem uczyć się (dotyczy to zwłaszcza duchownych), aby odmawiać czy śpiewać psalmy w duchu Nowego Testamentu. Kantyki zatem będą tutaj doskonałą pomocą w chrześcijańskim rozumieniu psalmów. Jeśli psalmy tajemnicę Chrystusa zapowiadają w sposób prorocki (oraz indirecte), to kantyki odnoszą się do tej tajemnicy bezpośrednio. Odnośnie zaś do usytuowania kantyków w strukturze nieszporów, to za ich umieszczeniem na końcu psalmodii przemawia motywacja chrystologiczna. Po prorockiej wymowie psalmów, śpiewający kantyk eksponują tajemnicę zbawczą Chrystusa, aby w końcu z radością wyśpiewać ewangelijny kantyk Magnificat.

W dniach 6-14 października 1966 Ojcowie Consilium wzięli udział w VII Sesji Plenarnej. Sekretarz Consilium A. Bugnini CM w swojej relacji dotyczącej sumarycznego opisu całości problematyki związanej z aktualnym stanem rewizji wszystkich ksiąg liturgicznych, kantykom poświęcił zaledwie jedno zdanie. Poinformował on, że Ojcowie zaakceptowali w całości (per manus elevationem) propozycję włączeni kantyków z Nowego Testamentu do nieszporów ${ }^{18}$. Warto tutaj przypomnieć, że Ojcowie równocześnie, w ogromnej większości $(32$ - placet, 2 non placet, 1 - placet iuxta modum) opowiedzieli się za występowaniem w jutrzni i nieszporach tylko trzech psalmów (lub ich części).

Bardziej detaliczny opis powyższej Sesji Plenarnej podaje sekretarz Grupy Studyjnej IX - V. Raffa ${ }^{19}$. W sposób bardziej precyzyjny przekazuje nam, że zadano pytanie czy Ojcowie są za taką strukturą psalmodii jutrzni i nieszporów, aby liczba trzech psalmów (lub ich części) obejmowała także odpowiednie kantyki, z zachowaniem odrębnej roli Benedictus czy Magnificat. Ponownie $32 \mathrm{Oj}$ ców głosowało placet, 2 - non placet, 1 - placet iuxta modum. W szczegółowej dyskusji nad tekstami i wyborem kantyków z Nowego Testamentu, bp C. G. Young chciałby, aby wśród kantyków znalazł się Prolog z Ewangelii św. Jana. Relator J. Pascher odpowiedział, że zgodna opinia egzegetów nie widzi w tym tekście literackiego charakteru kantyku. Podobne trudności zgłaszano wobec proponowanego tekstu 1 Kor 13,1-7 (canticum de caritate), gdyż zgodnie z poglądami św. Augustyna, co przypomniał znany patrolog bp M. Pellegrino, kantyki mają głosić chwałę Boga. W odpowiedzi J. Pascher podkreślał literackie piękno tego hymnu o miłości i proponował umieszczenie go w okresie Wielkiego Postu w miejsce kantyków allelujatycznych. Odnośnie do tego hymnu były także

\footnotetext{
${ }^{18}$ Zob. A. B u g n in i: Res Secretarius z dnia 28 października 1966, Relatio VII Sessionis Plenariae ,Consilii" 6-14 octobris 1966, s. 1-18, tutaj s. 10-11.

${ }^{19}$ Zob. Schemata n. 201, z dnia 8 listopada 1966, De Breviario 42, Relatio de his quae die 13 octobris in VII Sessione Plenaria Consilii, de Officio divino acta sunt, s. 1-11, tutaj s. 3 oraz 5.
} 
opinie pozytywne (bp H. Jenny, bp H. Volk), jakkolwiek zgłaszano zarazem ewentualne trudności związane z możliwością i sposobem ich wykonania śpiewem. Ogólnie jednak wszyscy Ojcowie Consilium (per elevationem manus) zgadzali się za włączeniem kantyków z Nowego Testamentu do nieszporów.

Następnym krokiem redakcyjnym w celu ustalenia struktury jutrzni i nieszporów było przeegzaminowanie przez Grupę Studyjną III pisemnych propozycji nadesłanych przez niektóre autorytety liturgiczne, specjalnie o to poproszo$\mathrm{ne}^{20}$. I tak J. Gelineau sugerował, aby w psalmodię dni niedzielnych wkomponować ewangelijne kantyki Benedictus czy Magnificat. W odpowiedzi usłyszał, że byłoby to zaprzeczeniem dotychczasowej, czcigodnej tradycji, która umieszczała te kantyki dopiero pod koniec tychże godzin kanonicznych, widząc w nich jakoby ich ukoronowanie. J. Gelineau chciałby ponadto, po konsultacji z egzegetami, poszerzyć zestaw kantyków ze Starego Testamentu przeznaczonych dla jutrzni. Można by tutaj czerpać z tradycji brewiarzy zakonnych. Odnośnie do kantyków nieszpornych, wspomniany ekspert odrzucał 1 Kor 13,1-7, a popierał wprowadzenie tekstu z prologu Ewangelii św. Jana. Te propozycje nie zyskały jednak przychylności Grupy Studyjnej III. Podobnie nie została przyjęta zaproponowana nowa struktura jutrzni czy nieszporów. J. Gelineau (et alius frater Gallus) chcieliby, aby te godziny rozpoczynały się od hymnu, a kończyły odpowiednimi kantykami. Konsultorzy natomiast z Grupy Studyjnej III uważali, że punkt ciężkości psalmodii omawianych godzin spoczywał na trzecim psalmie. W praktyce przeważała zatem opinia, aby w jutrzni kantyk ze Starego Testamentu znajdował się na drugim miejscu, a psalmodia znajdowała swoje ukoronowanie $\mathrm{w}$ trzecim psalmie o charakterze pochwalnym, zgodnie zresztą z tradycją rzymską. W nieszporach zaś culmen psalmodii wyraża odpowiedni kantyk z Nowego Testamentu „zastępujący” trzeci psalm. Dla ogólnie popieranego czterotygodniowego układu psałterza, streszczany tutaj dokument (Relatio) zapowiada, że będzie przygotowany zestaw podwójnej serii kantyków dla jutrzni, powtarzanych co dwa tygodnie, oraz jedna seria kantyków nieszpornych, przeznaczonych na każdy dzień w układzie jednego tygodnia, czyli powtarzanych przez następne trzy tygodnie.

W dniach 6-8 lutego 1967 r. pod przewodnictwem A. G. Martimorta w Genui, w Opactwie Najświętszej Maryi Panny Della Castagna odbyły się obrady z udziałem wszystkich relatorów (oraz zaproszonych ekspertów) odpowiedzialnych za nowe redakcje poszczególnych elementów księgi $B R^{21}$. Ustalono, że Grupa Studyjna III przygotuje poszerzony zestaw kantyków ze Starego Testa-

\footnotetext{
${ }^{20}$ Poniżej referujemy propozycje odnoszące się do kantyków zawarte w J. P a s c h e r: Relatio (provisoria) de psalmis ditribuendis z dnia 18 grudnia 1966, s. 1-5, tutaj s. 1-3.

${ }^{21}$ Zob. Schemata n. 206, z dnia 15 lutego 1967, Relatio Sessionis Coetus IX „,De structura generali Officii divini” quae Genuae apud Abbatiam S. Maria „Della Castagna” diebus 6. 7. 8. februarii 1967 habita est, s. 1-3, tutaj s. 2.
} 
mentu, przeznaczonych dla jutrzni w układzie czterotygodniowej psalmodii. Ponownie dyskutowano nad propozycją przeznaczenia tekstu „hymnu o miłości” (1 Kor 13,1-7) jako kantyku w nieszporach. Na 15 obecnych zaledwie 3 głosujących widziało ten tekst jedynie w okresie Wielkiego Postu (w niedzielę), pozostali odmawiali temu kantykowi charakteru hymnicznego. Większość dyskutantów (9 głosów) chciało zastąpić powyższy tekst kantykiem 1 P 2,21-24.

Miesiąc później Grupa Studyjna III ogłosiła pełny zestaw kantyków dla jutrzni w układzie psałterza rozłożonego na cykl czterech tygodni ${ }^{22}$. Zachowano dwie serie dotychczasowych, tradycyjnych kantyków obecnych w pierwszej i drugiej jutrzni $B R$. Dokonano przy tym postulowanych już wcześniej skróceń kantyków z ksiąg Powtórzonego Prawa (32,1-12), Wyjścia (15,1b-13.17-19) oraz Habakuka (3,2-4.12-19). Nowe, zaproponowane kantyki w zdecydowanej większości przejęte zostały z różnych tradycji zakonnych, praktykowanych od czasów starożytnych. Obejmowały one 8 tekstów z księgi Izajasza: 2,2-5; 26,1-10.12; 33,13-18; 40,10-17; 42,10-16; 49,7-15; 61,10-11.62,1-5; 66,10-14. Ponadto wybrano teksty z księgi Jeremiasza (14,17-21), z księgi Ezechiela (36,24-28) oraz z księgi Tobiasza (13,10-15.17-19). Spoza tradycji monastycznej wyszukano kantyk z księgi Mądrości 9,1-12. Dla dwóch niedziel chciano pozostawić dotychczasowe dwa kantyki z księgi Daniela („Pieśń trzech młodzieńców”): 3,52-57 oraz 3,57-58.56. Konsultorzy tejże Grupy Studyjnej w zdecydowany sposób odrzucali zgłaszane sugestie, które opowiadały się za włączeniem ewangelijnych kantyków (Benedictus czy Magnificat) w cykl psalmodii jutrzni czy nieszporów. W tradycji Kościoła cieszą się one specjalną godnością. Stanowią ukoronowanie modlitewne jutrzni czy nieszporów. Ich opuszczenie czy przeniesienie byłoby destrukcją struktury wspomnianych godzin kanonicznych.

Odnośnie do kantyków nieszporów, analizowany tutaj dokument nie wprowadza żadnych nowych tekstów z Nowego Testamentu. Aprobuje zestaw zgłoszonych już wcześniej kantyków ${ }^{23}$, dokonując równocześnie kilka uściśleń. Kantyk Ap 19,1-8 przeznaczono na niedziele, a Flp 2,6-11 na I nieszpory niedzieli ze względu na jego wymiar paschalny. Jeśli w przyszłości kantyk o miłości (1 Kor $13,1-7$ ) nie uzyska akceptacji (quia poesia huius pericopae non sit lyrica) aby umieścić go w nieszporach niedzielnych Wielkiego Postu, można by w jego miejscu umieścić tekst $1 \mathrm{P}$ 2,21-25. Ze względu na trudności ze znalezieniem większej ilości tekstów z Nowego Testamentu, które można by uznać za kantyki, należy pozostać przy idei powtarzania tych samych tekstów kantyków przez czterotygodniowy układ psalmodii.

\footnotetext{
${ }^{22}$ Pełny zestaw kantyków jutrzni oraz nieszporów podaje Schemata n. 212, z dnia 7 marca 1967, De Breviario 45, Coetus III. Relatio de distributione psalmorum, s. 1-11, tutaj s. 8-9.

${ }^{23}$ Por. przypis 16 .
} 
Wobec zbliżającej się VIII Sesji Plenarnej Consilium, wyznaczonej na 1017 kwietnia 1967 roku, A. G. Martimort in scriptis poinformował wszystkich konsultorów o przygotowaniu dla Ojców tejże Sesji próbnego „wzorca” (specimen) przyszłej księgi $B R$, z pełnymi tekstami Officium divinum dla jednego tygodnia (9-15 kwiecień 1967) oraz pełną dystrybucję psalmów dla pozostałych trzech tygodni ${ }^{24}$. Omawiając szczegółowo zawartość owego próbnego „wzorca”, odnośnie do kantyków A. G. Martimort poinformował, że kierowano się tutaj następującymi kryteriami redakcyjnymi, będącymi owocem i wynikiem prac Grupy Studyjnej III:

- w jutrzni do dotychczasowych kantyków dobrano wiele nowych tekstów z ksiąg Starego Testamentu;

- struktura psalmodii zachowuje podobny „,porządek zbawczy” jak w Lekcjonarzu mszalnym, czyli najpierw tekst ze Starego Testamentu, potem z Nowego (Listy Apostolskie, Dzieje Apostolskie, Apokalipsa) aż po tekst $\mathrm{z}$ Ewangeliii ${ }^{25}$;

- nie przewiduje się wprowadzenia innych kantyków z Ewangelii, poza tradycyjnymi Benedictus i Magnificat. Dotyczy to np. propozycji tekstu „Błogosławieństw” (Mt 5,3-11).

Bezpośrednio przed VIII Sesją Plenarną Consilium (10-19 IV 1967) zebrali się razem wszyscy relatorzy Grup przygotowujących rewizję poszczególnych elementów składowych przyszłej księgi $B R^{26}$. J. Pascher zapoznał obecnych m.in. z zestawem 26 kantyków ze Starego Testamentu oraz 7 z Nowego Testamentu. Ponownie, nieco dłużej zatrzymano się nad rolą kantyków Benedictus oraz Magnificat. Oto kilka charakterystycznych wypowiedzi:

J. Patino obawiał się występowania pewnej rutyny przy ich recytacji, jeśliby wspomniane ewangelijne kantyki obowiązywały codziennie;

J. Cellier opuściłby te dwa kantyki, aby nieco skrócić te dwie godziny kanoniczne;

${ }^{24}$ Zob. Schemata n. 215, z dnia 15 marca 1967, De Breviario 46, Relatio generalis de structura Breviarii Venerabiles Patres, s. 1-16, tutaj s. 3 n. Wspomniany specimen nosił tytuł: Schema completum Divinii Officii persolvendi a die 9 ad 15 aprilis 1967. Psalterium breviarii per quattuor hebdomadas distributum. In Civitate Vaticana 1967, s. 1-250.

${ }^{25} \mathrm{Tę}$ biblijną kolejność potwierdzi później Ogólne Wprowadzenie do Liturgii Godzin w art. 139.

${ }^{26}$ Informuje o tym (a także o odczytaniu w czasie VIII Sesji Plenarnej przez J. Pa s c h e r a w dniu 17 kwietnia 1967 relacji na temat dystrybucji psalmów zwłaszcza w jutrzni i nieszporach) Schemata n. 227, z dnia 9 maja 1967, De Breviario 48. De structura generali Officii divini, s. 1-16, tutaj s. 3. 
B. Fischer przekonywał, że koniecznie należy codziennie zachować te kantyki, gdyż wyrażają chwałę odkupienia i stanowią koronę duchowości officium;

H. M. Roguet przekonywał, że jeśli psalmy ze swej natury reprezentują elementy i treści profetyczne, to ewangelijne kantyki wykazują ich spełnienie, realizację;

B. Neunheuser podkreślał w tych kantykach ich wyjątkowy walor teologiczny, a także psychologiczny, potwierdzony ich wielowiekową obecnością w tradycji modlącego się Kościoła.

Ojcowie VIII Sesji Plenarnej w głosowaniu dotyczącym codziennego występowania Benedictus w jutrzni oraz Magnificat w nieszporach, jednogłośnie opowiedzieli się za utrzymaniem tejże praktyki.

W procesie dalszych prac Grupy Studyjnej III wyłaniały się dalsze propozycje tekstów kantyków, zarówno dla jutrzni, jak też nieszporów. I tak w połowie roku 1967 dobrano dla nieszporów niedziel Wielkiego Postu tekst 1 P 2,21-24 (Dobrowolna męka Chrystusa). Dla pierwszych nieszporów uroczystości Objawienia Pańskiego oraz święta Przemienienia Pańskiego przeznaczono tekst $1 \mathrm{Tm}$ 3,16 (Chwała Chrystusa). Tekst Iz 49,7-15 (Pieśń Sługi Pańskiego) zarezerwowany uprzednio na okres Adwentowy zastąpiono Kantykiem Azariasza Dn 3,26$27.29 .34-41^{27}$. Nie wszystkie powyższe propozycje znalazły się w ostatecznej redakcji księgi $B R$. Ukazują one jednakże proces redakcyjnego wysiłku konsultorów i ekspertów w dochodzeniu do finalnych ustaleń.

W październiku 1967 roku, z polecenia papieża Pawła VI zwołano Pierwszy Synod Biskupów świata, który miał przyjrzeć się posoborowej odnowie Kościoła, w tym także odnowie liturgicznej. 21 października przewodniczący Consilium kard. J. Lercaro odczytał relację ukazującą aktualny stan prac związanych z wykonaniem postanowień Konstytucji Liturgicznej, w tym również kwestie związane $\mathrm{z}$ nową redakcją księgi $B R$. W relacji przygotowanej dla przewodniczącego Consilium na temat kryteriów rewizji wspomnianej księgi, poza ukazaniem nowej struktury jutrzni i nieszporów, przypomniano, że novum w postaci wprowadzenia kantyków z Nowego Testamentu do nieszporów było już postulowane w dyskusjach Soboru Watykańskiego II ${ }^{28}$.

\footnotetext{
${ }^{27}$ Powyższe szczegóły, a także obszerne propozycje przypisujące poszczególne kantyki dla pierwszych i drugich nieszporów wielu świąt i uroczystości podaje Schemata n. 224, z dnia 20 września 1967, De Breviario 59, Coetus a studiis III: De psalmis distribuendis, s. 1-17.

${ }_{28}$... In disceptatione conciliari a pluribus Patribus optabatur ut in Breviario dicerentur cantica ex Novo Testamento depromenda, zob. Consilium ad exsequendam Constitutionem de Sacra Liturgia, Relatio ad Synodum Episcoporum de principiis ad instaurationem Breviarii, (bez daty), s. 1-7, tutaj s. 2.
} 
Ojcowie Synodu Biskupów w kwestii kantyków nie wnieśli żadnych istotnych poprawek czy propozycji. Jedynie dwóch dyskutantów (kard. V. Gracias oraz bp H. Jenny) opowiadali się za pozostawieniem w nieszporach kantyku o miłości (1 Kor 13,1-7) ${ }^{29}$.

Ostateczny zestaw kantyków przeznaczonych dla jutrzni zawiera 26 tekstów przydzielonych na każdy dzień czterotygodniowego układu księgi Liturgii Godzin. Pierwsze dwa tygodnie dni powszednich otrzymały zasadniczo tradycyjne kantyki z pierwszej i drugiej jutrzni tradycji utrwalonej w $B R$ Piusa $\mathrm{X} \mathrm{z}$ roku 1911. Wyjątkiem jest tutaj nowy kantyk na sobotę I tygodnia. Jest to Hymn zwycięstwa Mojżesza po przejściu Morza Czerwonego (Wj 15,1b-3.17-18) ze swoją symboliką sakramentu chrztu. Na pozostałe powszednie dni trzeciego i czwartego tygodnia przydzielono, wzmiankowane już wcześniej w niniejszym opracowaniu, nowe kantyki obecne w różnych zakonnych tradycjach brewiarzowych. Wyjątkiem jest tutaj kantyk tradycji hiszpańskiej Dn 3,26-27.29.34-41 ${ }^{30}$ występujący we wtorek czwartego tygodnia (modlitwa w piecu ognistym) oraz zupełnie nowy tekst przydzielony na sobotę trzeciego tygodnia z Księgi Mądrości 9,1-6.9-11 (Modlitwa o mądrość) ${ }^{31}$. Na niedziele wyznaczono dwa kantyki stanowiące dwie części „Pieśni Trzech Młodzieńców” z księgi Daniela, które na przemian powtarza się co dwie niedziele (Dn 3,52-57 oraz Dn 3,57-88.56).

Kantyki nieszporów, zupełne novum w przeredagowanej księdze $B R$, czerpane z Listów Apostolskich oraz Apokalipsy, umieszczone są zawsze po dwóch psalmach. Zestawione są one zasadniczo w cyklu jednego tygodnia, czyli powtarzane przez pozostałe trzy tygodnie układu brewiarzowej psalmodii ${ }^{32}$. I tak w niedziele występuje kantyk z Ap 19,1-2.5-7; w poniedziałki Ef 1,3-10; we wtorki Ap 4,11:5,9.10.12; w środy Kol 1,12-20; w czwartki Ap 11,17-18:12,1012; w piątki Ap 15,3-4; w soboty (1 nieszpory niedzielne) Flp 2,6-11. Ponadto ustalono, że w niedzielne drugie nieszpory okresu Wielkiego Postu będzie występował tekst $1 \mathrm{P}$ 2,21-24, a kantyk 1 Tm 3,16 będzie obecny w pierwsze nieszpory uroczystości Objawienia Pańskiego oraz w Święto Chrztu Pańskiego, a także w drugie nieszpory święta Przemienienia Pańskiego.

${ }^{29}$ Propozycje, zastrzeżenia, opinie Ojców Synodu na tematy związane z przyszłą redakcją księgi BR podaje Schemata n. 263, z dnia 10 grudnia 1967, De Breviario 45, Relatio IX Sessionis Consilii et praecedentis coadunationis relatorum necnon et Coetus IX, s. 1-18, tutaj s. 4.

${ }^{30}$ Dokumentuje to J. P i n e 11: Liturgia delle Ore. Torino 1990 s. 139.

${ }^{31}$ Tamże, s. 142.

${ }^{32}$ Zgodnie z tematem rozprawy analizujemy procesy redakcyjne oraz finalne ustalenia związane z nowym kształtem księgi BR, której nadano tytuł Liturgia Horarum (editio typica 1971). Jeśli bowiem oryginał łaciński operuje 9 tekstami kantyków nieszpornych, to już przekład polski Liturgii Godzin. vol. I-IV, Pallottinum 1982, zawiera ich aż 17; w tym kantyk - hymn o miłości (1 Kor 13,1-8.13) nieobecny w editio typica. Szczegółową analizę kantyków (zarówno w jutrzni, jak też w nieszporach) obecnych w polskiej edycji Liturgii Godzin prezentuje W. Gło w a: Modlitwa liturgiczna. Liturgia Godzin. Przemyśl 1996 s. 82-103. 
Studium nasze nie poruszało szerzej problematyki związanej z ewangelijnymi kantykami jutrzni i nieszporów (Benedictus oraz Magnificat). Poza marginalnymi opiniami niektórych konsultorów i ekspertów na temat ich roli w tychże godzinach kanonicznych, podważającymi ich codzienne występowanie w modlitwie brewiarzowej ${ }^{33}$, wyjątkowy szacunek i wielowiekowa tradycja Kościoła rzymskiego przypisująca tymże kantykom specjalne miejsce i rolę sprawia, że nadal „mają być one otaczane taką samą czcią i godnością, z jaką słuchamy słów Ewangelii" ${ }^{34}$.

\section{Bibliografia}

Głowa W.: Modlitwa liturgiczna. Liturgia Godzin. Przemyśl 1996.

Martimort A.G.: La Chiesa in preghiera. Introduzione alla liturgia. Brescia 1984.

Pinell J.: Liturgia delle Ore. Torino 1990.

Schemata. Grupa Studyjna III (De psalmis distribuendis ) od nr 5 do $\mathrm{nr} 263$.

Stefański J.: Dystrybucja psalmów w posoborowej reformie księgi Liturgii Godzin. Kwestie redakcyjne. „Roczniki Liturgiczne” T. 56: 2009 nr 1 s. 449-479.

Stefański J.: Prace redakcyjne nad posoborowa księga Liturgii Godzin. Konspekt historyczny. W: Mirabile laudis canticum. Liturgia Godzin: Dzieje i teologia. Red. H. Sobeczko. Opole 2008 s. 115-136.

\section{ABSTRACT}

\section{The position and role of the Canticles in Book of the Liturgy of the Hours. Editorial questions}

The former Roman Breviary contained only canticles of the Old Testament (with the exception of the Gospel Canticles), which occurred in a one week in laudes I and laudes II. This article describes several years of editorial work of the Study Group III Consilium, that led to its inclusion in the new book of the Liturgy of the Hours enlarged the amount of canticles of laudes and especially, for the first time, in vespers and some feasts (canticles of the New Testament).

Key words: reform of the breviary, canticles, liturgy of the hours.

Słowa kluczowe: reforma brewiarza, kantyki, liturgia godzin.

\footnotetext{
${ }^{33}$ Zob. dokumenty wymienione w przyp. 15 oraz 22.

${ }^{34}$ Zob. Ogólne Wprowadzenie do Liturgii Godzin. art. 139.
} 